\title{
Utilization of Waxy Corn Starch as an Efficient Chain Extender for the Preparation of Polyurethane Elastomers
}

DOI:

10.1016/j.ijbiomac.2020.01.011

10.1016/j.jijbiomac.2020.01.011

\section{Document Version}

Accepted author manuscript

Link to publication record in Manchester Research Explorer

\section{Citation for published version (APA):}

Javaid, M. A., Zia, K. M., Iqbal, A., Ahmad, S., Akram, N., Liu, X., Nawaz, H., Khosa, M. K., \& Awais, M. (2020). Utilization of Waxy Corn Starch as an Efficient Chain Extender for the Preparation of Polyurethane Elastomers. International Journal of Biological Macromolecules, 148, 415-423. https://doi.org/10.1016/j.ijbiomac.2020.01.011, https://doi.org/10.1016/j.ijbiomac.2020.01.011

\section{Published in:}

International Journal of Biological Macromolecules

\section{Citing this paper}

Please note that where the full-text provided on Manchester Research Explorer is the Author Accepted Manuscript or Proof version this may differ from the final Published version. If citing, it is advised that you check and use the publisher's definitive version.

\section{General rights}

Copyright and moral rights for the publications made accessible in the Research Explorer are retained by the authors and/or other copyright owners and it is a condition of accessing publications that users recognise and abide by the legal requirements associated with these rights.

\section{Takedown policy}

If you believe that this document breaches copyright please refer to the University of Manchester's Takedown Procedures [http://man.ac.uk/04Y6Bo] or contact uml.scholarlycommunications@manchester.ac.uk providing relevant details, so we can investigate your claim.

\section{OPEN ACCESS}




\section{Utilization of Waxy Corn Starch as an Efficient Chain Extender for the Preparation of Polyurethane Elastomers}

\section{HIGHLIGHTS}

- Waxy corn starch has been utilized as a substitute of 1,4-BDO at different moles ratio.

- Reaction of starch in the PU was monitored by FTIR spectroscopy.

- Structural characterization was done by using NMR spectroscopy.

- GPC was used to confirm the role of starch as a chain extender.

- Thermal degradation behavior of PUs was influenced by using starch. 


\title{
Utilization of Waxy Corn Starch as an Efficient Chain Extender for the Preparation of Polyurethane Elastomers
}

\begin{abstract}
Waxy corn starch modified polyurethane elastomers were synthesized by step growth polymerization reaction between $\mathrm{NCO}$-terminated prepolymer and chain extenders (1,4butanediol/starch). Isophorone diisocyanates (IPDI) was reacted with hydroxyl terminated polybutadiene (HTPB) to synthesize prepolymer that was reacted with different moles of 1,4butanediol (1,4-BDO) and starch to produced five samples of polyurethane. These specimens were analyzed by Fourier transformed infrared (FTIR) and proton Nuclear Magnetic Resonance $\left({ }^{1} \mathrm{H}\right.$ NMR) spectroscopy to determine the structural information. However, role of starch as chain extender was examined by gel permeation chromatography (GPC). Additionally, starch increased the thermal stability of PUs as compared to the conventional chain extender (1,4-BDO). Over all, this work has been designed to develop biodegradable polyurethanes that could be used in biomedical systems.
\end{abstract}

Keywords: Polyurethane Elastomers; Waxy Corn Starch; Biomaterial; Thermal Behavior 


\section{Utilization of Waxy Corn Starch as an Efficient Chain Extender for the}

2

3

4

5

6 a Department of Chemistry, University of Agriculture, Faisalabad 38040-Pakistan.

7 b Department of Applied Chemistry, Government College University, Faisalabad 38030-

8 Pakistan

$9{ }^{\mathrm{c}}$ Department of Chemistry, Government College University, Faisalabad 38030-Pakistan.

$10{ }^{d}$ Department of Materials, University of Manchester, Oxford Road, Manchester, UK

11 e Department of Chemistry, Quaid-i-Azam University, Islamabad 45320, Pakistan

12

13

14

15

16

17

18

19

20

21

22

23

24

25

\section{Preparation of Polyurethane Elastomers}

Muhammad Asif Javaid ${ }^{a}$, Khalid Mahmood Zia ${ }^{b},{ }^{*}$, Amer Iqbal $^{a}$, Saliha Ahmad ${ }^{\mathrm{c}}$, Nadia

Akram $^{\mathrm{c}}$, Xuqing Liu ${ }^{\mathrm{d}}$, Hifza Nawaz ${ }^{\mathrm{e}}$, Muhammad Kaleem Khosa ${ }^{\mathrm{c}}$, Muhammad Awais ${ }^{\mathrm{c}}$

* Corresponding author

Dr. Khalid Mahmood Zia (Corresponding Author)

E-mail address: ziakmpkpolym@yahoo.com

Fax: +92-(41)-9200671; Tel: +92-(300)-660396 
Utilization of Waxy Corn Starch as an Efficient Chain Extender for the Preparation of

27

28

\title{
Polyurethane Elastomers
}

\author{
ABSTRACT
}

Waxy corn starch modified polyurethane elastomers were synthesized by step growth polymerization reaction between NCO-terminated prepolymer and chain extenders $(1,4-$ butanediol/starch). Isophorone diisocyanates (IPDI) was reacted with hydroxyl terminated polybutadiene (HTPB) to synthesize prepolymer that was reacted with different moles of 1,4butanediol $(1,4-B D O)$ and starch to produced five samples of polyurethane. These specimens were analyzed by Fourier transformed infrared (FTIR) and proton Nuclear Magnetic Resonance $\left({ }^{1} \mathrm{H}\right.$ NMR) spectroscopy to determine the structural information. However, role of starch as chain extender was examined by gel permeation chromatography (GPC). Additionally, starch increased the thermal stability of PUs as compared to the conventional chain extender (1,4-BDO). Over all, this work has been designed to develop biodegradable polyurethanes that could be used in biomedical systems.

Keywords: Polyurethane Elastomers; Waxy Corn Starch; Biomaterial; Thermal Behavior

\section{Introduction}

The polymer industry currently relies heavily on the fossil fuels based raw materials which are non-renewable energy resources because it took millions of years for them to attain the present form. As consumption rate of fossil fuels is escalating gradually to fulfill our energy needs and if we continue to utilize them at the same rate; they will be exhausted soon. On the other hand, these traditional non-biodegradable plastics synthesized from fossil fuels also drastically disturbed and harmed our ecosystems [1-6] by releasing noxious and greenhouse gases like $\mathrm{CO}_{2}, \mathrm{CO}, \mathrm{NO}_{\mathrm{x}}$ etc. Thus the depletion of petroleum products along with other environmental issues i.e. greenhouse effect, global warming, management of waste etc. have raised the concerns in researchers to find novel cost effective, renewable and ecofriendly 
51 alternatives. Thus keeping in view the ecological and economical perspective: the

52 international demand to substitute fossil fuel based materials by the biodegradable resources

53 for the preparation of ecofriendly materials; being an area of consideration along immense

54 outcome for sustainable progress [7, 8]. From last decade, natural or bio based synthetic

55 polymers have attained significant attention in academic and industrial research.

56 Starch is the most famous polysaccharide derived from enzymatic hydrolysis of starch having material usually regarded as safe (GRAS) [14]. Starch has been successfully used in the form D-glucose units linked by $\alpha-(1 \rightarrow 4)$ or $\alpha-(1 \rightarrow 6)$ glycosidic bonds [9] and has various applications such as in binding agent in paper processing, medicine, food processing and textile finishing [10]. In food processing, starch is used as a crispness enhancer in the fried food, foam stabilizer in beer, to replace fats and sugar in low calories foods and binder in pills or as carrier in multivitamin tablets. Additionally, it could be employed as coatings and filler in food butters [11]. Due to presence of free hydroxyl groups, amylose starch is easily soluble in water at room temperature as compared to other polysaccharides. The solubility, biocompatibility, and biodegradability of starch offer great potential for applications in the polymer. Starch is classified as a food additive by the European Union and coded in E number 1400 and added in the group of supplementary chemicals (E1100-1599) (CAC, 2009). The extent of starch hydrolysis is called as "dextrose equivalent" (DE) that determine the reducing power of starch $[12,13]$. Even the starch with same DE exhibit different properties i.e. solubility, viscosity, stability, hygroscopicity, biocompatibility, and gelation which might be attributed to different structural features [12]. Therefore, various types of starches can be produced by varying hydrolysis conditions and respective source of starch that could be employed for specific applications. Starch is economically cheap bio-based raw of hydrogel for drug delivery system $[15,16]$ and bone regeneration and as wound dressing 
agent [17]. Starch based stimuli responsive hydrogel shows efficient magnetic and de novo

\section{drug delivery system especially theranostic applications [18-20].}

\section{Table 1}

Feed composition of 1,4-BDO/starch modified polyurethanes.

Polyurethane, a diverse class of polymeric materials with innumerable properties and applications i.e. construction, insulating material, composite wood, automotive, flooring, insulation, packaging, vehicle parts, medical instruments, etc. [2-5, 21]. All applications of polyurethanes are based on their properties that indirectly depend upon the chemical nature of reactants used (polyols, isocyanates, chain extender) and the reaction conditions. Therefore, polyurethanes are extensively used in various industries by manipulating its chemical route in diverse ways [22-24]. Mostly polyols and polyisocyanates undergo poly addition reaction to form urethanes linkage in the PUs backbone. PU is comprised of hard and soft domains that produced phase separation allowing these polymeric materials to withstand stresses easily [25-27]. PUs have superior thermo-mechanical properties, easy process-ability that give a big hand in the industrial development [28]. It has been reported, surface modification of PU can be done by using gamma irradiation, ultra-violet irradiation and interfacial modification with carbohydrate derivatives and polyethylene glycol to enhance hydrophilicity[29, 30], thermal properties and good antifouling activities against bacteria [29]. Polystyrene based composites have also been fabricated with clay to improve the thermal properties of PUs [31]. As discussed above, the major problem faced by the polymer industry in these days is to substitute non-renewable resources with renewable resources. Thus different polyurethanes blends have been synthesized by employing bio based raw material such as cellulose, chitin, chitosan, and starch for attaining the biocompatible [32-35]. However, starch has not been much incorporated in polyurethane industry to make PU biocompatible and biodegradable. Therefore, this research work aims to synthesize the starch modified polyurethanes that could 
be used in biomedical applications. In this research plan, we hydrolyzed waxy corn starch by

101 the acid hydrolysis and employed as chain extender in combination with 1,4-BDO to synthesized cost effective, biocompatible and biodegradable polyurethane elastomers.

\section{Experimental}

\subsection{Materials}

Dimethylformamide (DMF, $\geq 99.0 \%$ ) Isophorone diisocyanate (IPDI, $\geq 98 \%$ ), polycaprolactone diol (PCL, $\geq 99.0 \%$ ), dimethyl sulfoxide (DMSO, $\geq 97 \%$ ) and 1,4butanediol (1,4-BDO, $\geq 99 \%)$ were purchased from Sigma-Aldrich fine chemicals (St. Louis, MO, USA). Waxy corn starch was kindly gifted by Rafhan Maize products, Faisalabad 38000, Pakistan. GPC chromatogram of waxy corn starch after acid hydrolysis is represented in the supporting information. Flexible spacer (HTPB) and chain extenders (starch and 1,4BDO) were demoisturized for $24 \mathrm{~h}$ at $90{ }^{\circ} \mathrm{C}$ under vacuum; for the extermination of interfering materials (water and solvent) prior to use. The solvents, reagents, and chemicals used in this work were used without any further treatment.

Fig. 1(a)

Schematic of APU-1 preparation

\subsection{Synthesis of 1,4-BDO based PU composite (APU-1)}

Prepolymer was prepared by the condensation reaction between a diisocyanate and a polyol by a method reported in the literature $[36,37]$. By following the literature procedure, a prepolymer was developed by the reaction of HTPB $(0.00714 \mathrm{~mol} ; 21.5 \mathrm{~g})$ and IPDI $(0.0214$ mol; 3.6g) keeping their molar ratio (1:3). The temperature of the reaction mixture was gradually raised to $65^{\circ} \mathrm{C}$. The reaction of IPDI and HTPB was continued for 1 hour at $100^{\circ} \mathrm{C}$ and the rate of reaction has been monitored by the back titration method and FTIR spectroscopy. During reaction optimization, it was observed that the prepolymer was formed within an hour. The final PU was synthesized by the addition of 1,4-BDO (0.0142 mol; 
$1.28 \mathrm{~g}$ ) into the PU prepolymer as a chain extender. The reaction mixture has been stirred for

40 minutes at $90{ }^{\circ} \mathrm{C}$ to prepare the ultimate polymer. When the homogeneity developed in the flask, it indicated the reaction of chain extender and prepolymer has been formed. Finally, the reaction mixture was poured into the Teflon mold to develop the uniform film of polyurethane. To remove the air bubbles this developed PU was evacuated under vacuum then this polymer was cured by keeping it in oven for 24 hours at $100{ }^{\circ} \mathrm{C}$. The developed films were then stored at ambient temperature for one week. The general reaction mechanism of 1,4-BDO based PU is schematically shown in Fig. 1(a).

Fig. 1(b)

Schematic of APU-2-APU-4 preparation

\subsection{Synthesis of 1,4-BDO and starch based PUs (APU-2-APU-4) and pristine starch}

\section{(APU-5)}

Prepolymer was synthesized by following the procedure as discussed in the preparation of APU-1 in section 2.2. However, in the next step, 1,4-BDO (0.00714 mol; $0.64 \mathrm{~g})$ and starch $(0.0047 \mathrm{~mol} ; 1.61 \mathrm{~g})$ blends were added for the preparation of starch based PU (APU-3) composite. The demoisturized starch was dissolved in the DMSO and used as chain extender along with 1,4-BDO in different molar ratio as shown in Table 1 to prepare APU-2 to APU-4 samples. Schematic illustration for preparation of $1,4-\mathrm{BDO} /$ starch modified PUs is given in Fig. 1(b).

For the formation of $100 \%$ starch based PU (APU-5), prepolymer was prepared by the same methodology given in section 2.2. However, only modified starch was added as a substitute of 1,4-BDO in the last step. Schematic illustration for preparation of starch based polyurethane is shown in Fig. 1(c). After minor amendments in the composition five specimens of 1,4-BDO/starch based samples were prepared. PU sheets were kept for seven days at $25{ }^{\circ} \mathrm{C}$ and have less than $40 \%$ relative humidity before testing. 


\subsection{Measurements}

153 FTIR spectra of the prepared specimens were recorded using attenuated total reflection 154 (ATR) mode on NICOLET 380 Fourier transformed infrared spectrometer. All the spectra of 155 PU samples were recorded in absorbance mode with accumulation of 8 scan at a resolution of 156 $4 \mathrm{~cm}^{-1}$. The ${ }^{1} \mathrm{H}$ NMR spectrum of the PUs was recorded in deuterated dimethyl sulfoxide mode and are arranged in a specific order in Fig. 2. IR spectrum of HTPB (Fig. 2(a)) shows (DMSO-d6) as solvent using a $600 \mathrm{MHz}$ Bruker Avance II NMR spectrometer (Bruker BioSpin Corporation, Switzerland). All chemical shifts $(\delta)$ were recorded in ppm were referenced to tetra methoxy silane (TMS). Molecular weight distributions and molecular weights were measured by gel permeation chromatography (GPC, Agilent 1100, USA). GPC was equipped with IR detector using tetrahydrofuran (THF) as mobile phase (eluent) at a rate of $1.0 \mathrm{mLmin}^{-1}$ and the temperature of column was maintained at $35{ }^{\circ} \mathrm{C}$. All specimens were prepared in THF then solution was filtered by a micro-filter $(3 \mathrm{~mm})$. Ten different molecular weights $\left(2000-5,000,000 \mathrm{gmol}^{-1}\right)$ of polystyrenes were used as standards of GPC. Thermal gravimetric analysis (TGA) was performed using TGA Q500V6.3 Build 189. Approximately $5-6 \mathrm{mg}$ of the specimen cut from the sheet was equilibrated at room temperature, then subjected to TGA measurement from 25 to $500^{\circ} \mathrm{C}$ instrument in an inert atmosphere of argon gas (the flow rate was $50 \mathrm{~mL} \mathrm{~min} \mathrm{~m}^{-1}$ ). The mass loss with respect to temperature and maximum degradation temperature of specimens were recorded.

\section{Results and discussion}

\subsection{FTIR-ATR analysis of PUs}

The FTIR-ATR scans of all the reactants and intermediate steps were taken in the absorption the presence of four meaningful bands. A wide absorption band at $3350 \mathrm{~cm}^{-1}$ is related to the 
stretching frequency of $-\mathrm{OH}$ groups. A sharp band merged with a shoulder band in the range 2800-3000 $\mathrm{cm}^{-1}$ is ascribed to stretching frequency of $\mathrm{sp}^{2}$-hybridized $-\mathrm{CH}_{2}$ units. A sharp but low intensity absorption band at $1625 \mathrm{~cm}^{-1}$ is ascribed with aliphatic $-\mathrm{C}=\mathrm{C}-$ groups and high intensity sharp band below $1000 \mathrm{~cm}^{-1}$ represents bending frequency associated with long chain of $-\mathrm{CH}$ in HTPB $[2,5]$. FTIR spectrum of IPDI is depicted in Fig. 2(b). This figure clearly shows two significant bands, one around $2900 \mathrm{~cm}^{-1}$ represents the stretching frequency of methylene groups $\left(-\mathrm{CH}_{2}-\right)$ and other band appeared at $2400 \mathrm{~cm}^{-1}$ corresponds to the stretching frequency of isocyanate group. Bands below $1000 \mathrm{~cm}^{-1}$ show the presence of meta-substitution in IPDI.

Firstly, NCO-endcapped PU prepolymer was synthesized by the reaction of IPDI and HTPB; FTIR graph of prepolymer is depicted in Fig. (2c). In the prepolymer scan, a new band was appeared at $3300 \mathrm{~cm}^{-1}$ along with medium intensity band at $1550 \mathrm{~cm}^{-1}$ attributed to stretching frequency of $\mathrm{NH}_{2}$ groups and presence of $\mathrm{NH}$ groups respectively. The carbonyl bands of urethane groups was found at $1650 \mathrm{~cm}^{-1}$ while the bands of $-\mathrm{OH}$ groups $\left(3400 \mathrm{~cm}^{-1}\right)$ and relatively high intensity band of $-\mathrm{NCO}$ groups $\left(2200 \mathrm{~cm}^{-1}\right)$ were reduced. This observation indicated that $\mathrm{NCO}-$ endcapped PU prepolymer has been developed. Also the band of - NCO in IPDI has been decreased and a new band for - NH group has been appeared which showed that reaction has been done between HTPB and IPDI and prepolymer has successfully been prepared $[5,38,39]$. Others significant bands in the prepolymer spectrum are: $1726 \mathrm{~cm}^{-1}$ 194 (carbonyl stretching), hydrogen bonded carbonyl group (1596 cm $\mathrm{cm}^{-1}$ stretching), $1531 \mathrm{~cm}^{-1}$ 195 (-NH deformations), $1450 \mathrm{~cm}^{-1}$ (methylene group bending vibrations), $2900 \mathrm{~cm}^{-1}\left(-\mathrm{CH}_{2}\right.$ 196 stretching vibrations), $1161 \mathrm{~cm}^{-1}\left(\mathrm{C}-\mathrm{O}-\mathrm{C}\right.$ absorption); $1414 \mathrm{~cm}^{-1}$ are due to the $-\mathrm{CH}$ 197 bending vibration. However, $-\mathrm{NH}$ absorption at $3339 \mathrm{~cm}^{-1}$ and $\mathrm{NCO}$ absorption at $2249 \mathrm{~cm}^{-1}$ confirmed the synthesis of prepolymer. Then the prepolymer was reacted with 1,4-BDO (chain extender) to form resultant polyurethane. The FTIR graph of 1,4-BDO (Fig. 2d) shows 
two major bands, one broad band at $3400 \mathrm{~cm}^{-1}$ confirmed the existence of hydroxyl group in

201 the structure and one medium intensity bands with a shoulder at $2850 \mathrm{~cm}^{-1}$ showed the 202 presence of $\mathrm{CH}_{2}$ group in the structure. FTIR spectrum of pure starch is shown in Fig. 2d that 203 exhibits broad band of $-\mathrm{OH}$ groups in the range of $3000-3451 \mathrm{~cm}^{-1}$. This broad band is 204 ascribed to the extensive H-bonding in starch structure. The absorptions at 2848 and 2914 whereas, bands ranging from $1040-1000 \mathrm{~cm}^{-1}$ associated to $\mathrm{C}-\mathrm{O}-\mathrm{C}$ stretching vibrations. FTIR spectrum of PU prepared with the starch and 1,4-BDO (APU-3) is shown in Fig. 2e. The complete disappearance of isocyanate band at $2248 \mathrm{~cm}^{-1}$ and increase in the height of -NH stretching band (urethane group) at $3291 \mathrm{~cm}^{-1}$ implies the formation of suggested polymeric structure. The other bands designated as, $1711 \mathrm{~cm}^{-1}$ (carbonyl stretching), $2915 \mathrm{~cm}^{-}$ ${ }^{1}\left(\mathrm{CH}_{2}\right.$ symmetrical stretching), $1529 \mathrm{~cm}^{-1}$ (NH deformations), $1649 \mathrm{~cm}^{-1}$ (hydrogen bonding carbonyl stretching), $1598 \mathrm{~cm}^{-1}$ (N-H stretching), $1418 \mathrm{~cm}^{-1}$ (C-N stretching vibration), 1166 $\mathrm{cm}^{-1}$ correspond to $\mathrm{C}-\mathrm{O}-\mathrm{C}$ stretching vibration and band at $1444 \mathrm{~cm}^{-1}$ (methylene bending vibration). The $-\mathrm{NH}$ band at $3292 \mathrm{~cm}^{-1}, 1711 \mathrm{~cm}^{-1}, 1649 \mathrm{~cm}^{-1}$ of $-\mathrm{C}=\mathrm{O}$ bond stretching vibrations and $-\mathrm{CHN}$ stretching band at $1533 \mathrm{~cm}^{-1}$ implies that this polymer have urethane linkages in its background. All bands in the spectra of final PU demonstrated that the reaction has been completed and the designed polyurethane was effectively synthesized.

Fig. 2

FT-IR spectral presentation of ultimate PU prepared with 1,4-BDO/starch blends (APU-3)

\section{2 ${ }^{1} \mathrm{H}$ NMR spectroscopy}

${ }^{1} \mathrm{H}$ NMR spectrum of neat starch was recorded at $600 \mathrm{MHz}$, in DMSO-d6 (as solvent) and shown in Fig. 3(a). The peaks at $\delta=5.44,5.36$ and 3.32-3.39 ppm are ascribed to the anomeric protons, anomeric protons ( $<5 \%$ 1,6-linakage are generally represent), and protons 
of polysaccharides ring $\left(\mathrm{H}_{\mathrm{b}}-\mathrm{H}_{\mathrm{e}}\right)$ respectively. The peaks at $\delta=4.9-5.1 \mathrm{ppm}$ are ascribed to the

225 hydroxyl moieties present on the polysaccharide ring [40, 41].

\section{Fig. 3(a)}

${ }^{1} \mathrm{H}$ NMR spectra of pristine starch

The ${ }^{1} \mathrm{H}$ NMR spectrum of neat PU prepared with only 1,4-BDO is represented in Fig. 3(b) and characterized by following peaks: the methyl proton of IPDI $(\mathrm{H} 7, \mathrm{H} 8)$ were observed at 0.83-0.95 ppm, the methylene proton of polyol HTPB give peaks at $3.30 \mathrm{ppm}(\mathrm{H} 1), 5.35 \mathrm{ppm}$ (H2), 2 ppm (H3), 1.2 ppm (H4) and 4.95 ppm (H5) [42]. Whereas the proton of $\mathrm{NH}$ of urethanes gives two characteristic peaks: one at $7.05 \mathrm{ppm}(\mathrm{H} 6)$ and other at $7.70 \mathrm{ppm}\left(\mathrm{H} 6^{\prime}\right)$. The peak of methylene unit of 1,4-BDO was appeared at $3.96 \mathrm{ppm}(\mathrm{H} 9)$.

Fig. 3(b)

${ }^{1} \mathrm{H}$ NMR spectra of 1,4-BDO based polyurethane (APU-1)

The ${ }^{1} \mathrm{H}$ NMR spectrum of starch /1,4-BDO (1:1) based PU is depicted in Fig. (3c), various new peaks have been observed due to the incorporation of starch along with 1,4-BDO. Peaks observed in the ${ }^{1} \mathrm{H}$ NMR spectrum of starch (Fig. 3(a)) have also been observed in the APU-3 that demonstrated that reaction has been done between prepolymer and new chain extender (starch). Such as a broad but relatively low intensity peak at $5.3 \mathrm{ppm}$ attributed to $-\mathrm{OH}$ proton of starch moiety $\left(\mathrm{Hg}\right.$ and $\left.\mathrm{Hg}^{\prime}\right)$ along with sharp and intense peak of $\mathrm{H}_{\mathrm{b}}, \mathrm{H}_{\mathrm{d}}$ protons of starch at $3.35 \mathrm{ppm}$. These are some new peaks that are not present in the ${ }^{1} \mathrm{H}$ NMR spectra of PU prepared with 1,4-BDO explained in Fig. 3(b). Furthermore, lower chemical shift values $(0.8-2 \mathrm{ppm})$ were ascribed to the aliphatic protons of $-\mathrm{CH}_{3}$ moieties of IPDI and $-\mathrm{CH}_{2}$ unit of HTPB.

The $-\mathrm{CH}_{2} \mathrm{O}$ protons $(\mathrm{H} 9)$ of $1,4-\mathrm{BDO}$ and $-\mathrm{CH}_{2} \mathrm{O}$ proton $(\mathrm{H} 1)$ of $\mathrm{HTPB}$ were appeared at 3.5 ppm. The absorptions at $5.1 \mathrm{ppm}$ attributed to the protons $(\mathrm{H} 2, \mathrm{H} 5)$ of unsaturated carbons of HTPB. The protons (H6) of urethane moiety gave intense and sharp peak at 7.5-8.1 ppm. All 
of these NMR peaks has been confirmed that both the chain extenders $(1,4-\mathrm{BDO} / \mathrm{starch})$ successfully cross-linked with prepolymer.

Fig. 3(c)

${ }^{1} \mathrm{H}$ NMR spectra of 1,4-BDO/starch blends based polyurethane (APU-3)

The ${ }^{1} \mathrm{H}$ NMR spectrum of pristine starch based polyurethane is depicted in Fig. 3(d). The peaks of starch protons $\mathrm{H}_{\mathrm{a}}, \mathrm{H}_{\mathrm{b}}, \mathrm{H}_{\mathrm{d}}, \mathrm{H}_{\mathrm{e}}$ and $\mathrm{H}_{\mathrm{f}}$ were appeared at 5.6ppm, 3.6ppm, 3.2ppm and 4ppm respectively. The broadness of peaks of $\mathrm{H}_{\mathrm{b}}$ and $\mathrm{H}_{\mathrm{d}}$ protons of starch showed that these protons might cross-linked with prepolymer or these protons have been involved in hydrogen bonding with prepolymer backbone. The aliphatic protons of IPDI and backbone were appeared at 0.9-2.1ppm. However, the protons associated with unsaturated units were appeared at $5 \mathrm{ppm}$. The urethane $-\mathrm{NH}$ protons gave peaks at $7.1 \mathrm{ppm}(\mathrm{H} 6)$ and $8 \mathrm{ppm}(\mathrm{H} 6)$. AS DMSO have great affinity with water, therefore during handling and preparing samples some amount of moisture may become part of solution. Therefore, signal at $3.33 \mathrm{ppm}$ in all spectra is ascribed to the trace of water present in the $\left(\mathrm{CH}_{3}\right)_{2} \mathrm{SO}$ [43].

Fig. 3(d)

${ }^{1} \mathrm{H}$ NMR spectra of starch based polyurethane (APU-5)

\subsection{Gel permeation chromatography of Starch based polyurethanes}

Potential of starch as a chain extender for the polyurethane was evaluated by gel permeation chromatography (GPC). GPC chromatograms of PUs are represented in Fig. 4. The number average $(\mathrm{Mn})$ and weight average molecular weight distributions of PUs help to determine the role of carbohydrates as chain extender $[3,6]$. Mn and Mw of PUs were measured and presented in Table 2. GPC results help to find the role of starch as chain extender for the PU systems. It is evident from the results that with the increase in the starch concentration the molecular weights of PUs were increased sufficiently. GPC findings revealed that starch being polyhydroxy carbohydrate functioned as an efficient chain extender for the preparation 
274 of PUs. GPC chromatograms showed that the retention time for GPC curve of APU-1 (starch

275 free sample) is higher which indicated that molecular weight of APU-1 is smaller as

276 compared to the starch based polyurethanes. The intensity of starch free sample (APU-1) is

277 greater as compared to starch based samples which indicated that APU-1 have smaller chains

278 than other samples. The retention time of PUs lessened with increase in the starch

279 concentration in the PU backbone. This fact may be due to the longer chains produced due to

280 the multifunction starch molecules. It is very interesting, sample APU-5 (prepared with 100\%

starch) exhibited smallest intensity, it means with decrease in the concentration of 1,4-BDO the solubility of PU chains decreased. Multifunctional carbohydrates bears hydroxyl groups that provide multi- active sites for chain extension [44]. GPC results proved that starch is an efficient chain extender for the preparation of PU.

Fig. 4

GPC Chromatograms of starch based PUs

Table 2

GPC profile of Starch based polyurethanes

\subsection{Thermal gravimetric analysis of Starch based PUs}

TGA can yield vital information on a PU system, such as decomposition temperature and threshold limit temperature for a polymer to degrade on heating. The degradation temperatures corresponding to the different mass losses are summarized in Table $\mathbf{3}$, while the obtained TGA thermoanalytical curves are depicted in Fig. 5. The characteristic thermal degradation temperatures like initial decomposition temperature (Ti) and maximum temperature of degradation $\left(\mathrm{T}_{\max }\right)$ are given in Table 3 . The thermoanalytical curves of PUs gave three characteristic temperatures after specific time intervals; however, in the later two stages polymers experience significant mass loss. The initial mass loss (normally temperature at which $1 \%$ mass loss occur) found in the PUs at $60-120{ }^{\circ} \mathrm{C}$ temperature is ascribed to the 
evaporation of moisture, crystalline water and solvents [6]. Second stage $\left(280-410^{\circ} \mathrm{C}\right)$ may

tentatively be ascribed to the breakdown of carbamate linkages to hydroxyl and isocyanate

groups; which leads to further cracking of hydroxyl units [3]. However, third major weight

loss appeared in the temperature range from $420^{\circ} \mathrm{C}$ to $500{ }^{\circ} \mathrm{C}$, which was mainly ascribed

with the pyrolysis of the most complex segments probably polyol molecules. It is apparent

from the TGA results thermal stability of starch based PUs was improved by increasing the

starch contents in the PU matrix. The starch based PUs showed thermal stability at all

temperature as compared to neat PU, indicating that both hard and soft segments mutually

\section{CONCLUSION}

316 Starch modified polyurethane biomaterials were synthesized by reacting IPDI and HTPB; 317 extended with various molar ratio of 1,4-BDO and waxy starch. The spectroscopic 318 characterization (FTIR, ${ }^{1} \mathrm{H}$ NMR) of all samples were found according to proposed structure.

319 GPC results showed that starch act as better chain extender than conventional diol. Pristine 320 starch based PU exhibited higher molecular weight than neat 1,4-BDO based PU. Analysis of 321 TGA data showed that the incorporation of starch in the PU matrix enhanced the thermal 
stability of PUs. The whole study is a preliminary step to explore the potential of starch as chain extender for PU and can be preferred over conventional organic materials.

\section{REFERENCES}

325 [1] M. Darder, M. Colilla, E. Ruiz-Hitzky, Biopolymer- clay nanocomposites based on 326 chitosan intercalated in montmorillonite, Chem. Mater. 15(20) (2003) 3774-3780.

327 [2] M. A. Javaid, R. A. Khera, K.M. Zia, K. Saito, I. A. Bhatti, M. Asghar, Synthesis and 328 characterization of chitosan modified polyurethane bio-nanocomposites with biomedical potential, Int. J. Biol. Macromol. 115 (2018) 375-384.

[3] M. A. Javaid, M. Rizwan, R. A. Khera, K.M. Zia, K. Saito, M. Zuber, J. Iqbal, P. Langer,

Thermal degradation behavior and X-ray diffraction studies of chitosan based polyurethane bio-nanocomposites using different diisocyanates, Int. J. Biol. Macromol. (2018).

[4] M. A. Javaid, M. Younas, I. Zafar, R. A. Khera, K.M. Zia, S. Jabeen, Mathematical

modeling and experimental study of mechanical properties of chitosan based polyurethanes:

Effect of diisocyanate nature by mixture design approach, Int. J. Biol. Macromol. 124 (2019)

$336 \quad 321-330$.

337 [5] M. A. Javaid, K.M. Zia, R. A. Khera, S. Jabeen, I. Mumtaz, M. A. Younis, M. Shoaib, I.

338 A. Bhatti, Evaluation of cytotoxicity, hemocompatibility and spectral studies of chitosan

339 assisted polyurethanes prepared with various diisocyanates, Int. J. Biol. Macromol. 129 340 (2019) 116-126.

341 [6] M. A. Javaid, K.M. Zia, H.N. Ilyas, N. Yaqub, I. A. Bhatti, M. Rehan, M. Shoaib, A. 342 Bahadur, Influence of chitosan/1, 4-butanediol blends on the thermal and surface behavior of 343 polycaprolactone diol-based polyurethanes, Int. J. Biol. Macromol. 141 (2019) 1022-1034.

344 [7] X. Cao, L. Zhang, J. Huang, G. Yang, Y. Wang, Structure-properties relationship of 345 starch/waterborne polyurethane composites, J. Appl. Polym. Sci. 90(12) (2003) 3325-3332. 
346 [8] F. Zia, K.M. Zia, M. Zuber, S. Kamal, N. Aslam, Starch based polyurethanes: a critical

347 review updating recent literature, Carbohyd. Polym. 134 (2015) 784-798.

348 [9] S. Manchun, K. Cheewatanakornkool, C. R. Dass, P. Sriamornsak, Novel pH-responsive 349 dextrin nanogels for doxorubicin delivery to cancer cells with reduced cytotoxicity to 350 cardiomyocytes and stem cells, Carbohyd. Polym. 114 (2014) 78-86.

351 [10] K.M. Zia, A. Noreen, M. Zuber, S. Tabasum, M. Mujahid, Recent developments and 352 
371 [17] A. DeBusk, T. Alleman, Method for preparing medical dressings. Vol. US2006/0018955

372 A1. Powell, TN: DeRoyal Industries, Inc, 2006.

[18] B. Massoumi, Z. Mozaffari, M. Jaymand, A starch-based stimuli-responsive magnetite nanohydrogel as de novo drug delivery system, Int. J. Biol. Macromol. 117 (2018) 418-426. [19] N. Poorgholy, B. Massoumi, M. Jaymand, A novel starch-based stimuli-responsive nanosystem for theranostic applications, Int. J. Biol. Macromol. 97 (2017) 654-661.

[20] N. Masina, Y. E. Choonara, P. Kumar, L. C. du Toit, M. Govender, S. Indermun, V. Pillay, A review of the chemical modification techniques of starch, Carbohyd. Polym. 157 (2017) 1226-1236.

[21] I. Banik, M.M. Sain, Water blown soy polyol-based polyurethane foams of different rigidities, J. Reinf. Plast. Comp. 27(4) (2008) 357-373.

[22] S. Keskin, A. Usanmaz, Hydroxyl-terminated poly (urethane acrylate) as a soft liner in dental applications: Synthesis and characterization, J. Appl. Polym. Sci. 117(1) (2010) 458466.

[23] X. Liu, K. Xu, H. Liu, H. Cai, J. Su, Z. Fu, Y. Guo, M. Chen, Preparation and properties of waterborne polyurethanes with natural dimer fatty acids based polyester polyol as soft segment, Prog. Org. Coat. 72(4) (2011) 612-620.

[24] M. Sultan, K.M. Zia, H. N. Bhatti, T. Jamil, R. Hussain, M. Zuber, Modification of cellulosic fiber with polyurethane acrylate copolymers. Part I: Physicochemical properties, Carbohyd. Polym. 87(1) (2012) 397-404.

[25] J. Wen, G. Somorjai, F. Lim, R. Ward, XPS study of surface composition of a segmented polyurethane block copolymer modified by PDMS end groups and its blends with phenoxy, Macromolecules 30(23) (1997) 7206-7213. 
[26] V. Tangpasuthadol, S.M. Pendharkar, J. Kohn, Hydrolytic degradation of tyrosinederived polycarbonates, a class of new biomaterials. Part I: Study of model compounds, 396 Biomaterials 21(23) (2000) 2371-2378.

397 [27] M. Shoaib, A. Bahadur, S. Iqbal, M. S. U. Rahman, S. Ahmed, G. Shabir, M. A. Javaid, 398 Relationship of hard segment concentration in polyurethane-urea elastomers with mechanical, 399 thermal and drug release properties, J. Drug Deliv. Sci Tec. 37 (2017) 88-96.

400 [28] V. R. Journal of Food SciencePolymer ChemistryGowariker, N. Viswanathan, J. 401

Sreedhar, Polymer science, New Age International1986.

[29] P. Alves, J. Coelho, J. Haack, A. Rota, A. Bruinink, M. Gil, Surface modification and characterization of thermoplastic polyurethane, Eur. Polym. J. 45(5) (2009) 1412-1419.

[30] F. Meng, Z. Qiao, Y. Yao, J. Luo, Synthesis of polyurethanes with pendant azide groups attached on the soft segments and the surface modification with mPEG by click chemistry for antifouling applications, RSC Adv. 8(35) (2018) 19642-19650.

[31] M. Abbasian, M. Seyyedi, M. Jaymand, Modification of thermoplastic polyurethane through the grafting of well-defined polystyrene and preparation of its polymer/clay nanocomposite, Polym. Bull. (2019) 1-14.

[32] K. Kim, M. Hamdy, Depolymerization of starch by high pressure extrusion, J. FOOD Sci. 52(5) (1987) 1387-1390.

[33] K.M. Zia, S. Anjum, M. Zuber, M. Mujahid, T. Jamil, Synthesis and molecular characterization of chitosan based polyurethane elastomers using aromatic diisocyanate, Int. J. Biol. Macromol. 66 (2014) 26-32.

[34] A. Pei, J.-M. Malho, J. Ruokolainen, Q. Zhou, L. A. Berglund, Strong nanocomposite reinforcement effects in polyurethane elastomer with low volume fraction of cellulose nanocrystals, Macromolecules 44(11) (2011) 4422-4427. 
[35] A. Saralegi, L. Rueda, B. Fernández-d'Arlas, I. Mondragon, A. Eceiza, M. Corcuera,

419 Thermoplastic polyurethanes from renewable resources: effect of soft segment chemical 420 structure and molecular weight on morphology and final properties, Polym. Int. 62(1) (2013)

$421 \quad 106-115$.

422 [36] M. Barikani, C. Hepburn, The Relative Thermal Stability of Polyurethane Elastomers.

III. Influence of Chain Extender Structure, Cell. Polym. 6(2) (1987) 47-66.

[37] M. BariKani, C. Hepburn, Isocyanurate crosslinking as a means of producing thermally stable polyurethane elastomers, Cell. Polym. 5(3) (1986) 169-185.

[38] M. Fiayyaz, K.M. Zia, M. Zuber, T. Jamil, M. K. Khosa, M. A. Jamal, Synthesis and characterization of polyurethane/bentonite nanoclay based nanocomposites using toluene diisocyanate, Korean J. Chem. Eng. 31(4) (2014) 644-649.

[39] G. Chen, X. Guan, R. Xu, J. Tian, M. He, W. Shen, J. Yang, Synthesis and characterization of UV-curable castor oil-based polyfunctional polyurethane acrylate via 431 photo-click chemistry and isocyanate polyurethane reaction, Prog. Org. Coat. 93 (2016) 1143216.

[40] D. Das, P. Patra, P. Ghosh, A.P. Rameshbabu, S. Dhara, S. Pal, Dextrin and poly 434 (lactide)-based biocompatible and biodegradable nanogel for cancer targeted delivery of doxorubicin hydrochloride, Polym. Chem-UK 7(17) (2016) 2965-2975.

436 [41] D. Das, A.P. Rameshbabu, P. Patra, P. Ghosh, S. Dhara, S. Pal, Biocompatible 437 amphiphilic microgel derived from dextrin and poly (methyl methacrylate) for dual drugs 438 carrier, Polymer 107 (2016) 282-291.

439 [42] H. Daemi, M. Barikani, Molecular engineering of manipulated alginate-based 440 polyurethanes, Carbohyd. Polym. 112 (2014) 638-647.

441 [43] G. R. Fulmer, A. J. Miller, N. H. Sherden, H. E. Gottlieb, A. Nudelman, B.M. Stoltz, J. 442 E. Bercaw, K. I. Goldberg, NMR chemical shifts of trace impurities: common laboratory 
443 solvents, organics, and gases in deuterated solvents relevant to the organometallic chemist, 444 Organometallics 29(9) (2010) 2176-2179.

445 [44] K. Kamiyama, H. Onishi, Y. Machida, Biodisposition characteristics of N-succinyl-

446 chitosan and glycol-chitosan in normal and tumor-bearing mice, Biol. Pharm. Bull. 22(2) 


\section{Figure Captions:}

Fig. 1 (a) Schematic of APU-1 preparation; Fig. 1(b) Schematic of APU-2-APU-4 preparation; Fig. 1(c) Schematic of APU-5 preparation

Fig. 2 FT-IR spectra of final PU extended with 1, 4-BDO/starch blends (APU-3)

Fig. 3 (a) ${ }^{1} \mathrm{H}$ NMR spectra of pristine starch; Fig. 3(b) ${ }^{1} \mathrm{H}$ NMR spectra of 1,4-BDO based polyurethane (APU-1); Fig. 3(c) ${ }^{1} \mathrm{H}$ NMR spectra of 1,4-BDO/starch blends based polyurethane (APU-3); Fig. 3(d) ${ }^{1} \mathrm{H}$ NMR spectra of starch based polyurethane (APU-5)

Fig. 4 GPC chromatograms of starch based PUs

Fig. 5 TGA thermoanalytical curves of starch based PUs 


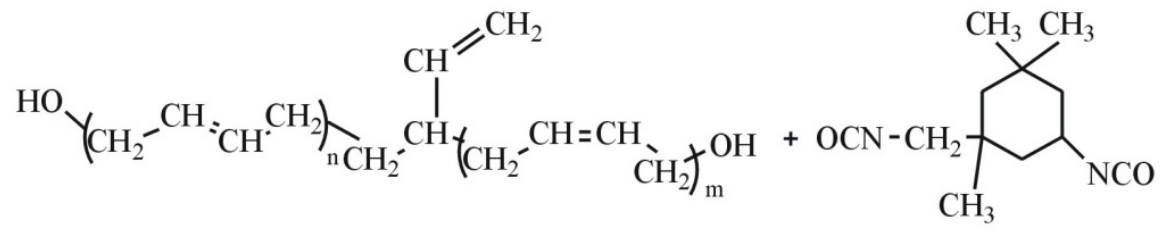

Hydroxyl terminated polybutadiene

Isophrone diisocyanate

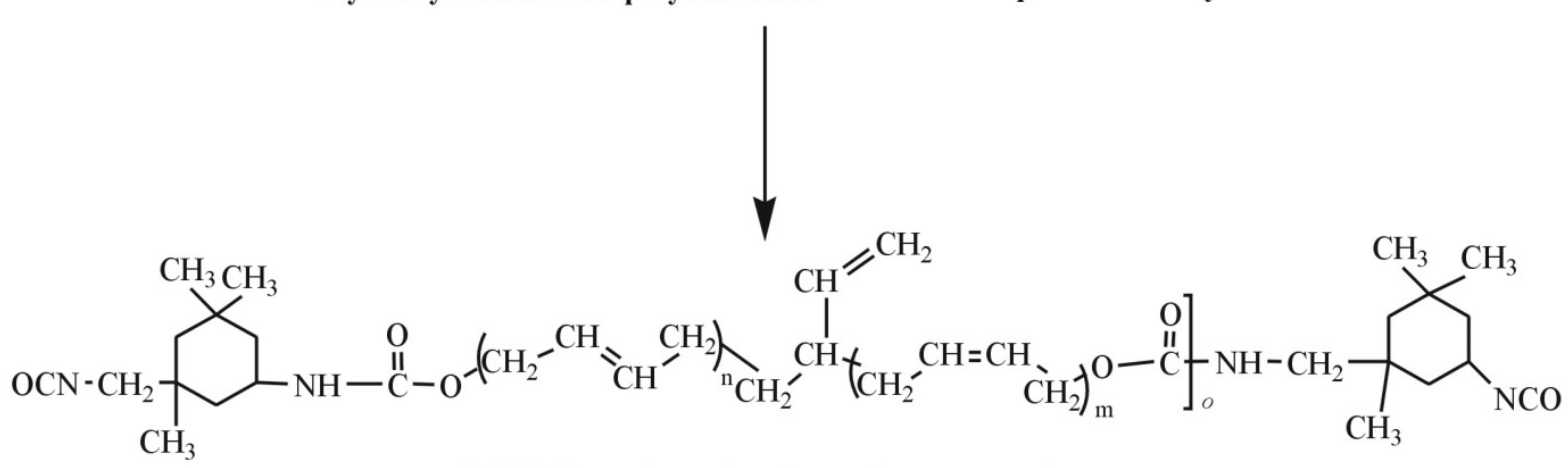

NCO-Terminated polyurethane prepolymer

$$
\begin{gathered}
\mathrm{HO}-\mathrm{CH}_{2}-\mathrm{CH}_{2}-\mathrm{CH}_{2}-\mathrm{CH}_{2}-\mathrm{OH} \\
\text { 1,4-Butane diol }
\end{gathered}
$$

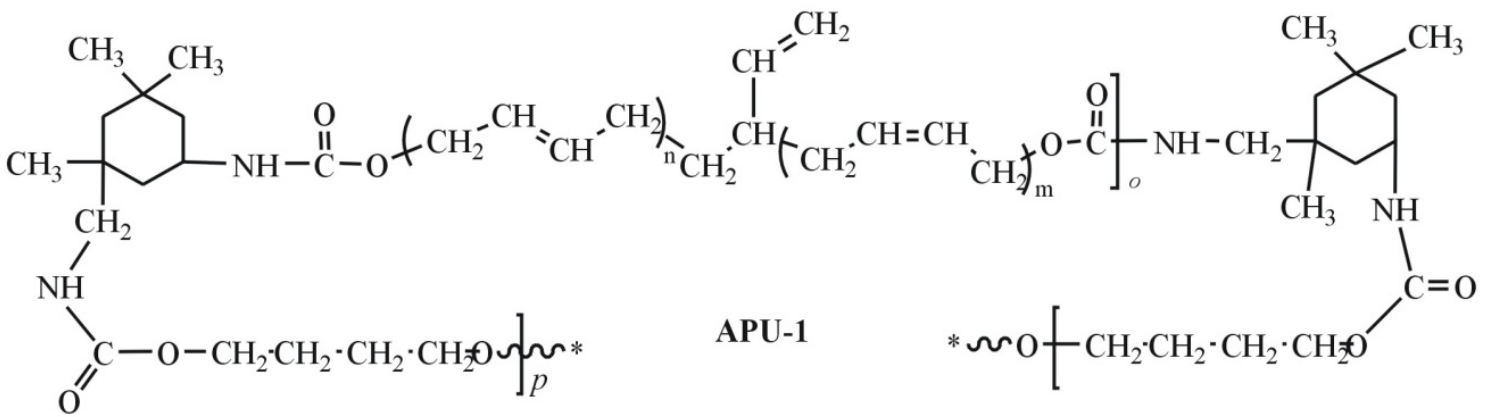

Fig. 1(a) 


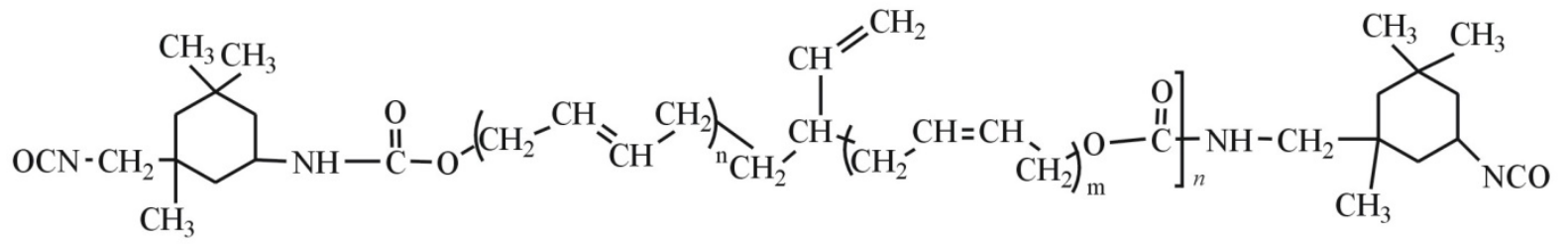
NCO-Terminated polyurethane prepolymer

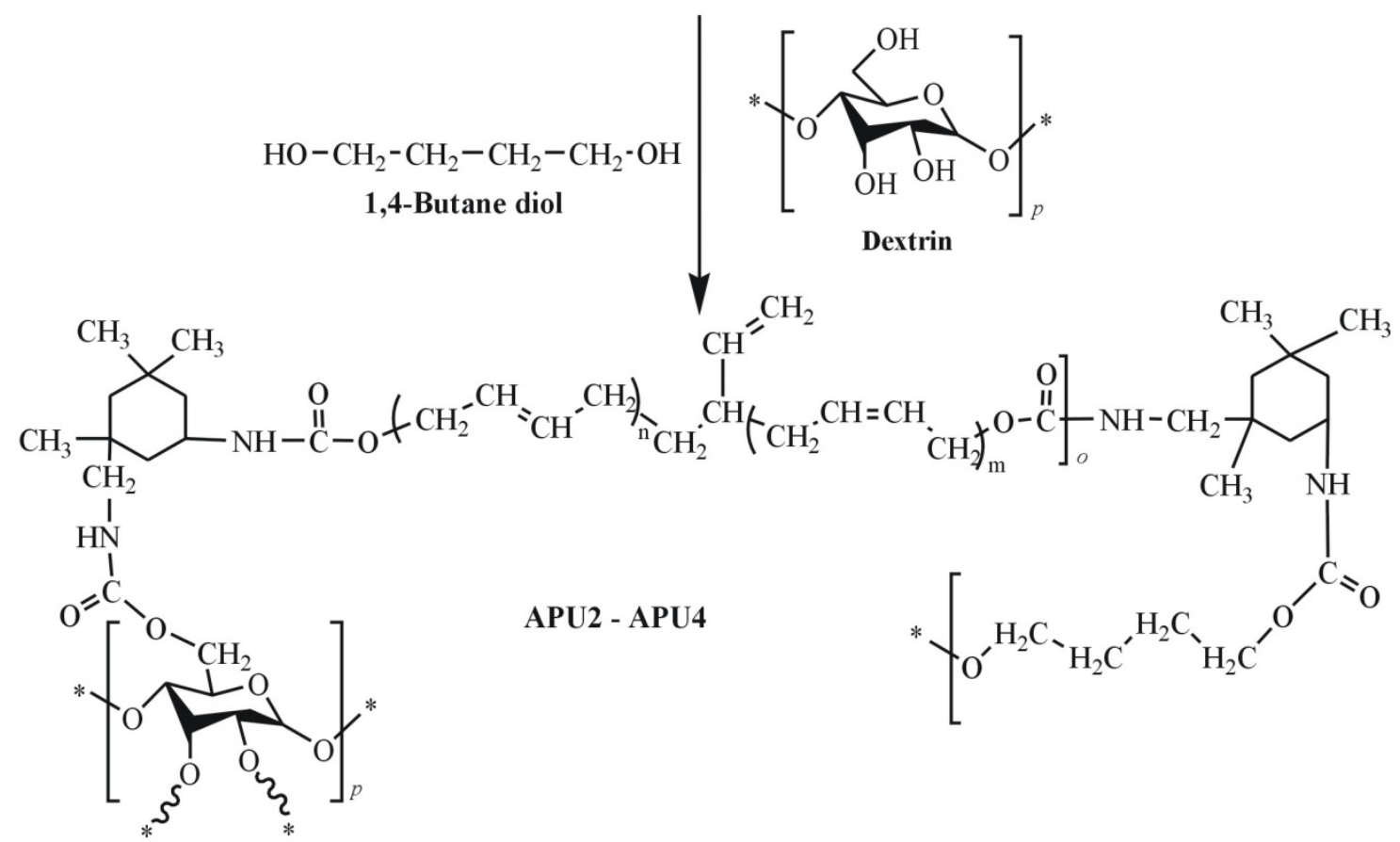

Fig. 1(b) 
<smiles>C=CC(CC=CCOC(=O)NCC1(C)CC([N+](=O)[O-])CC(C)(C)C1)CCC=CCCOC(=O)NC1CC(C)(C)CC(C)(CN=O)C1</smiles>
NCO-Terminated polyurethane prepolymer

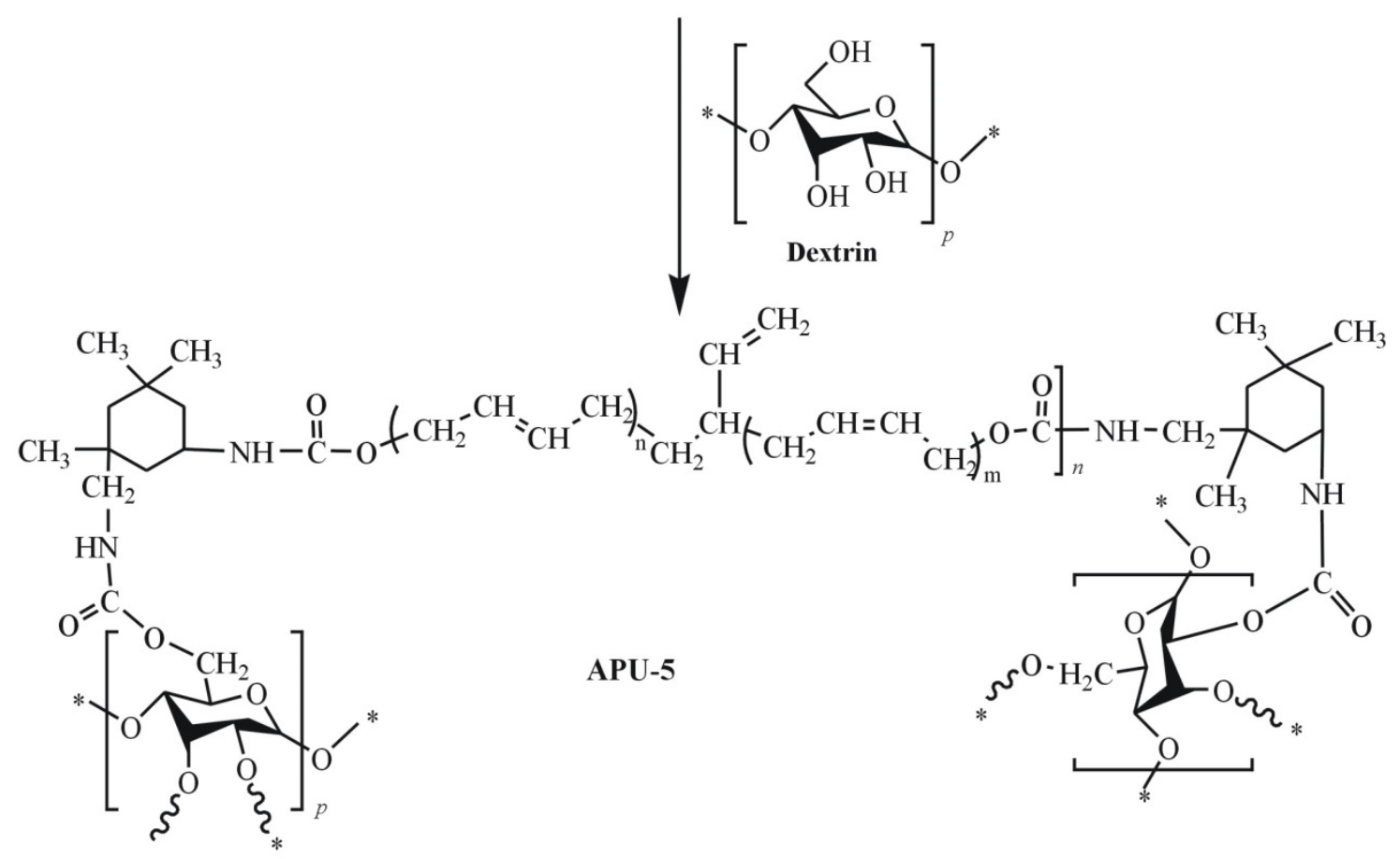

Fig. 1(c)

Fig. 1(a) Schematic of APU-1 preparation; Fig. 1(b) Schematic of APU-2-APU-4 preparation; Fig. 1(c) Schematic of APU-5 preparation 


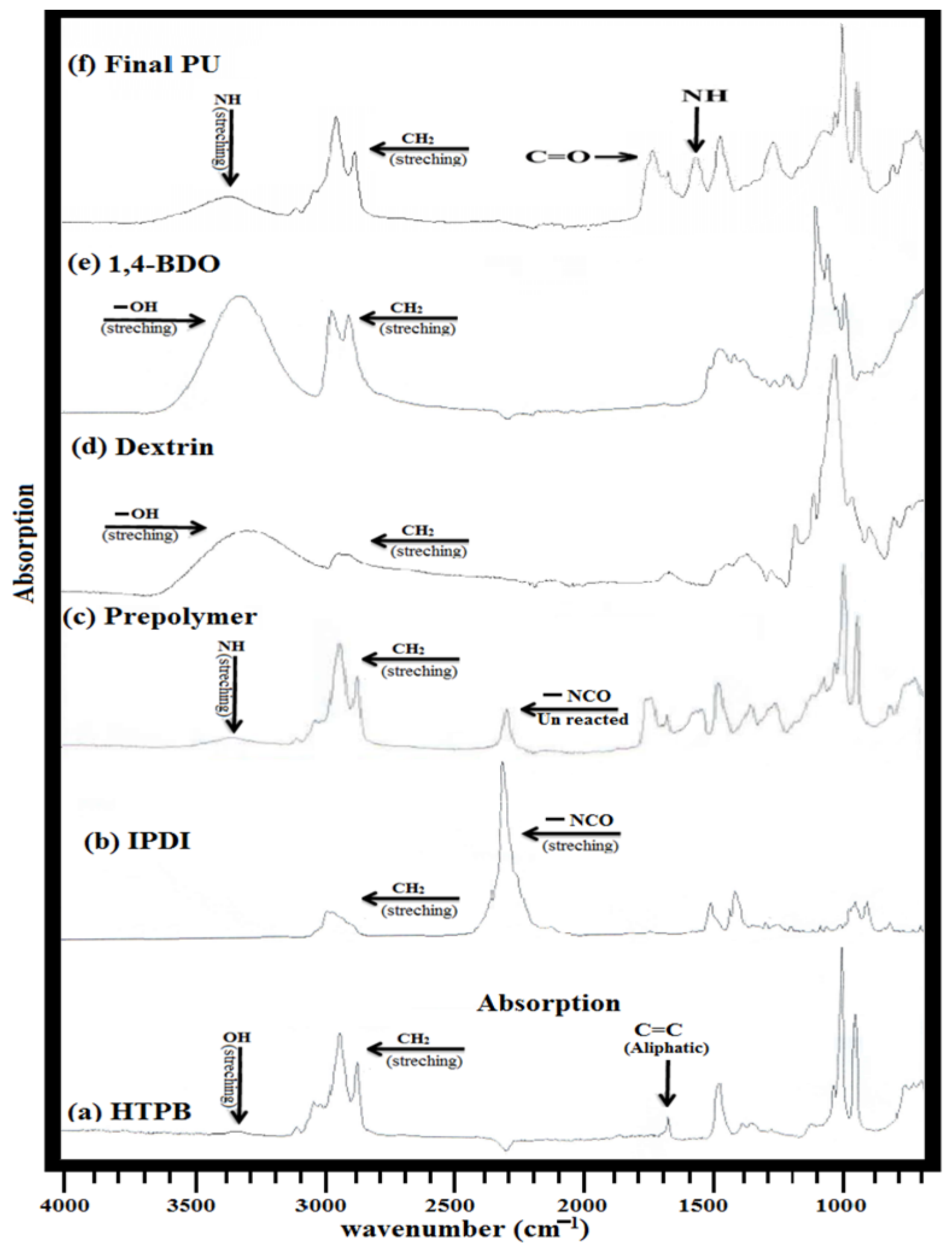

Fig. 2

FT-IR spectra of final PU extended with 1, 4-BDO/starch blends (APU-3) 


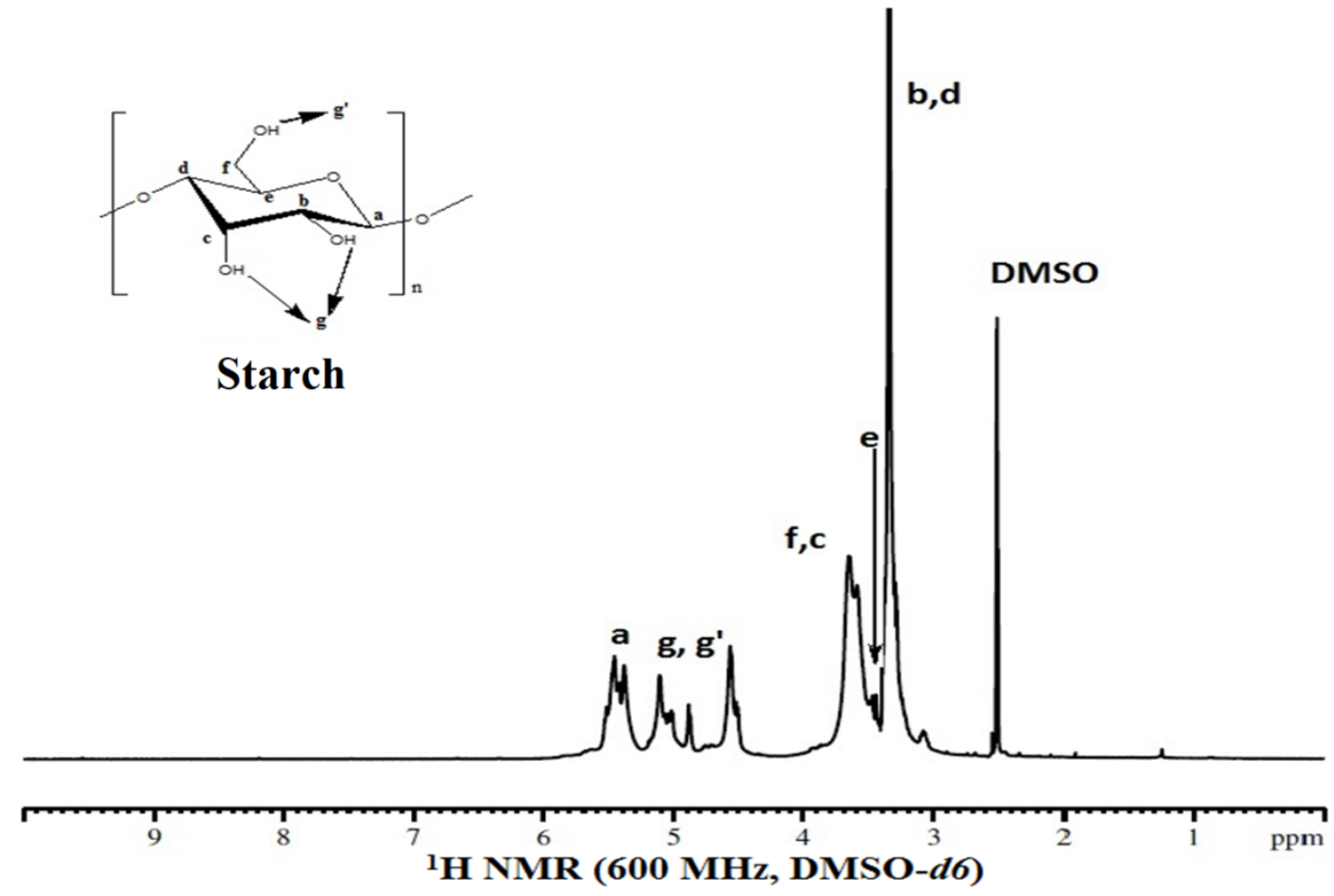

Fig. 3(a)

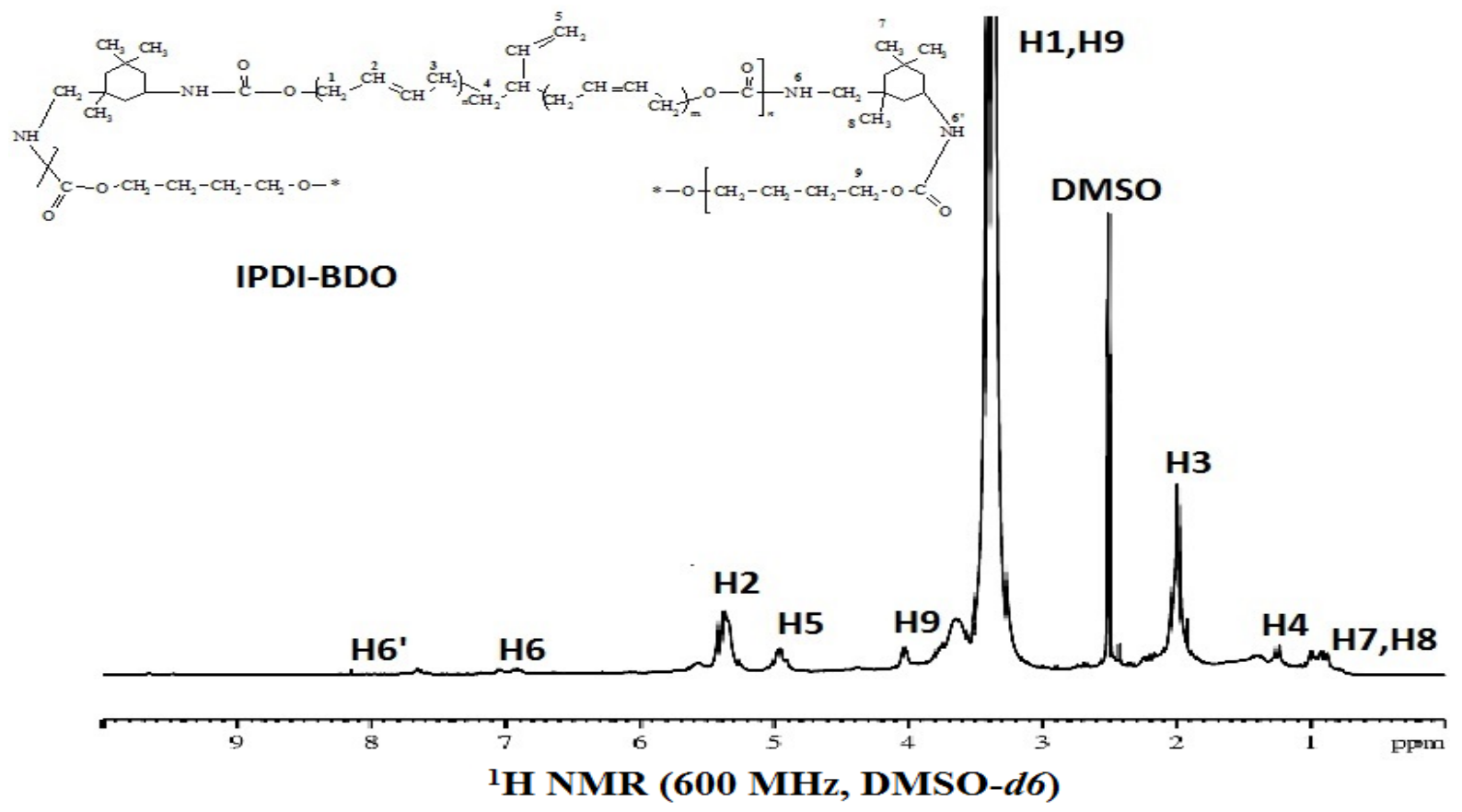

Fig. 3b 


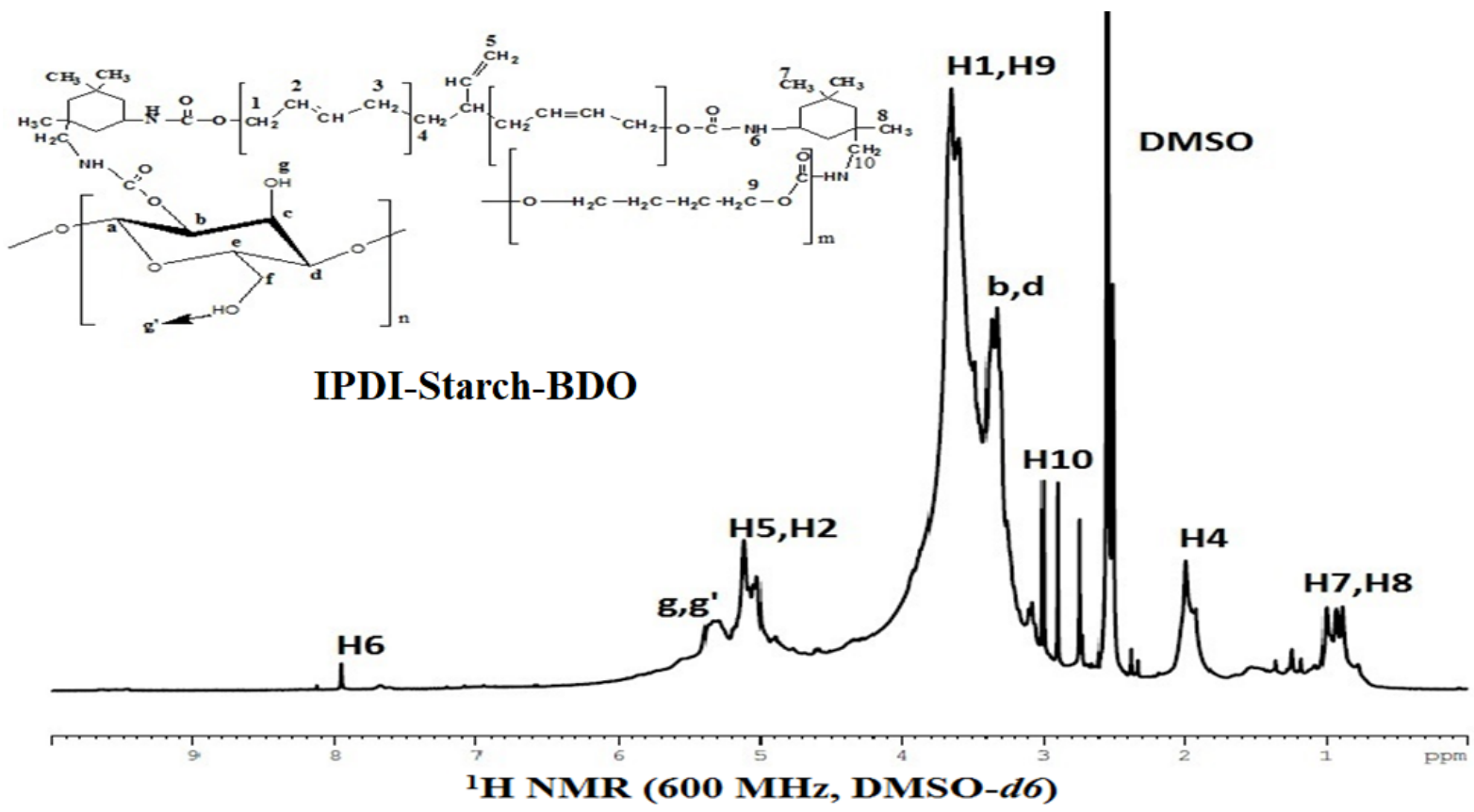

Fig. 3(c)

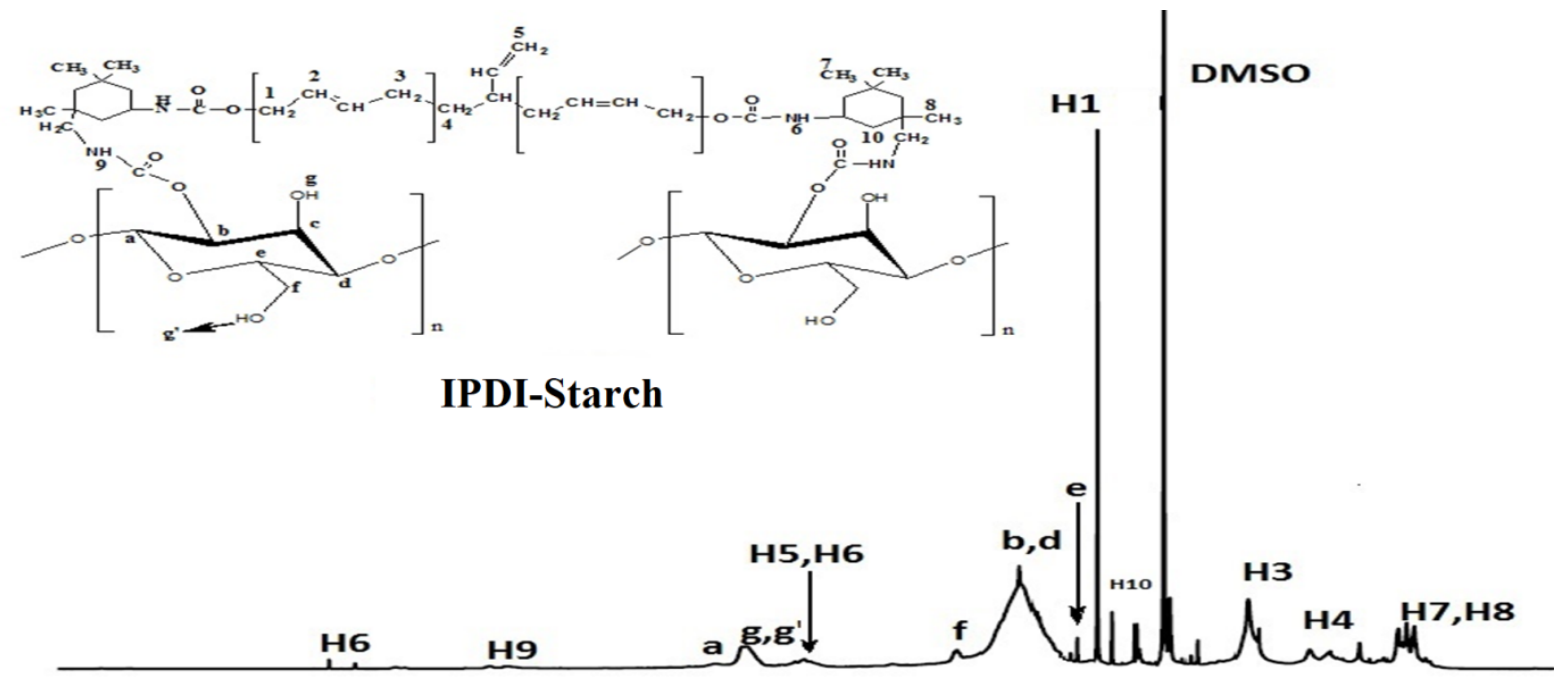

${ }^{1} H_{\text {NMR }}$ (6OO MHz, DMSO-do)

Fig. 3(d)

Fig. 3(a) ${ }^{1} \mathrm{H}$ NMR spectra of pristine starch; Fig. 3(b) ${ }^{1} \mathrm{H}$ NMR spectra of 1,4-BDO based polyurethane (APU-1); Fig. 3(c) ${ }^{1} \mathrm{H}$ NMR spectra of 1,4-BDO/starch blends based polyurethane (APU-3) ; Fig. 3(d) ${ }^{1} \mathrm{H}$ NMR spectra of starch based polyurethane (APU5) 


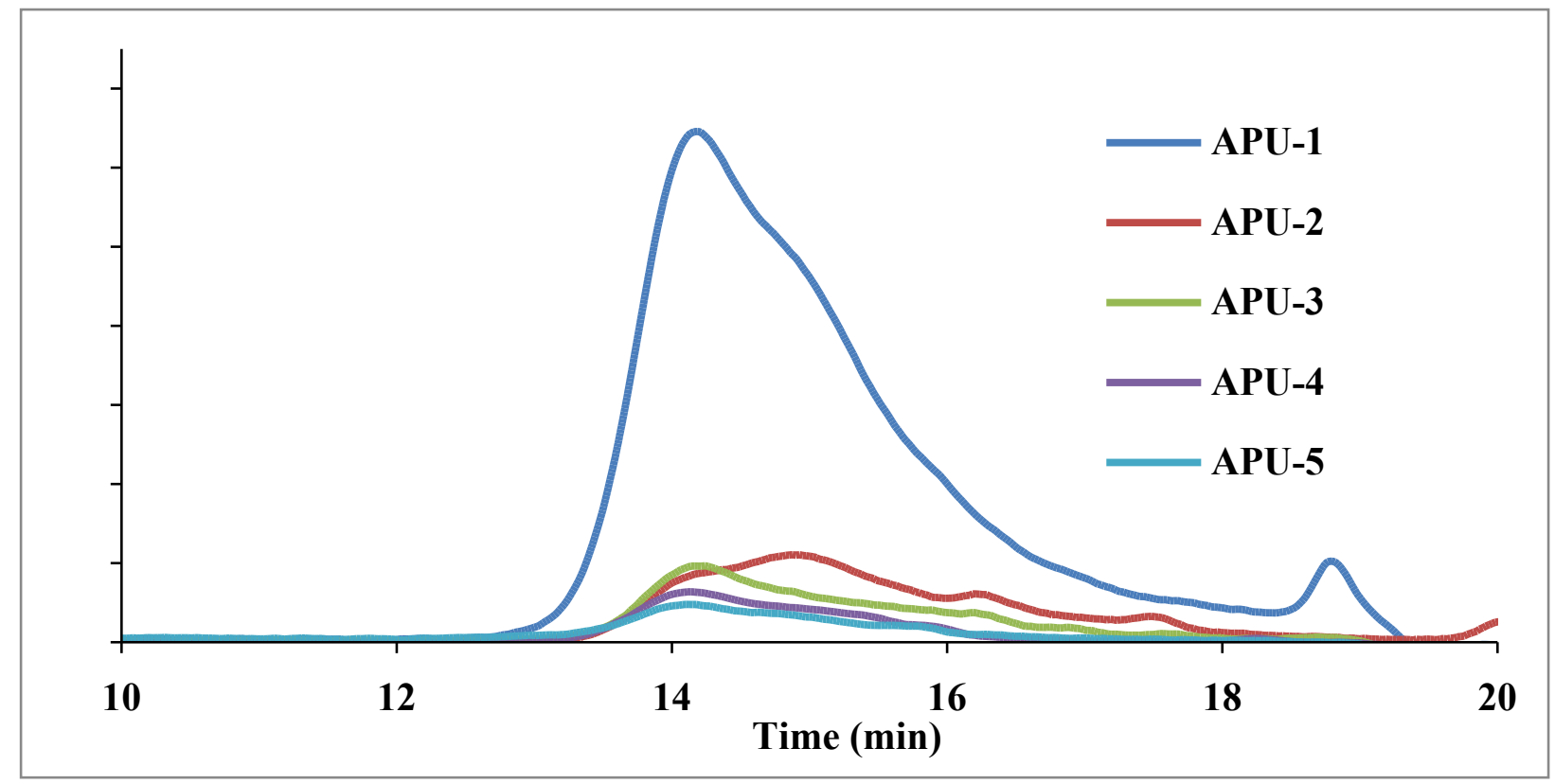

Fig. 4

GPC Chromatograms of starch based PUs 


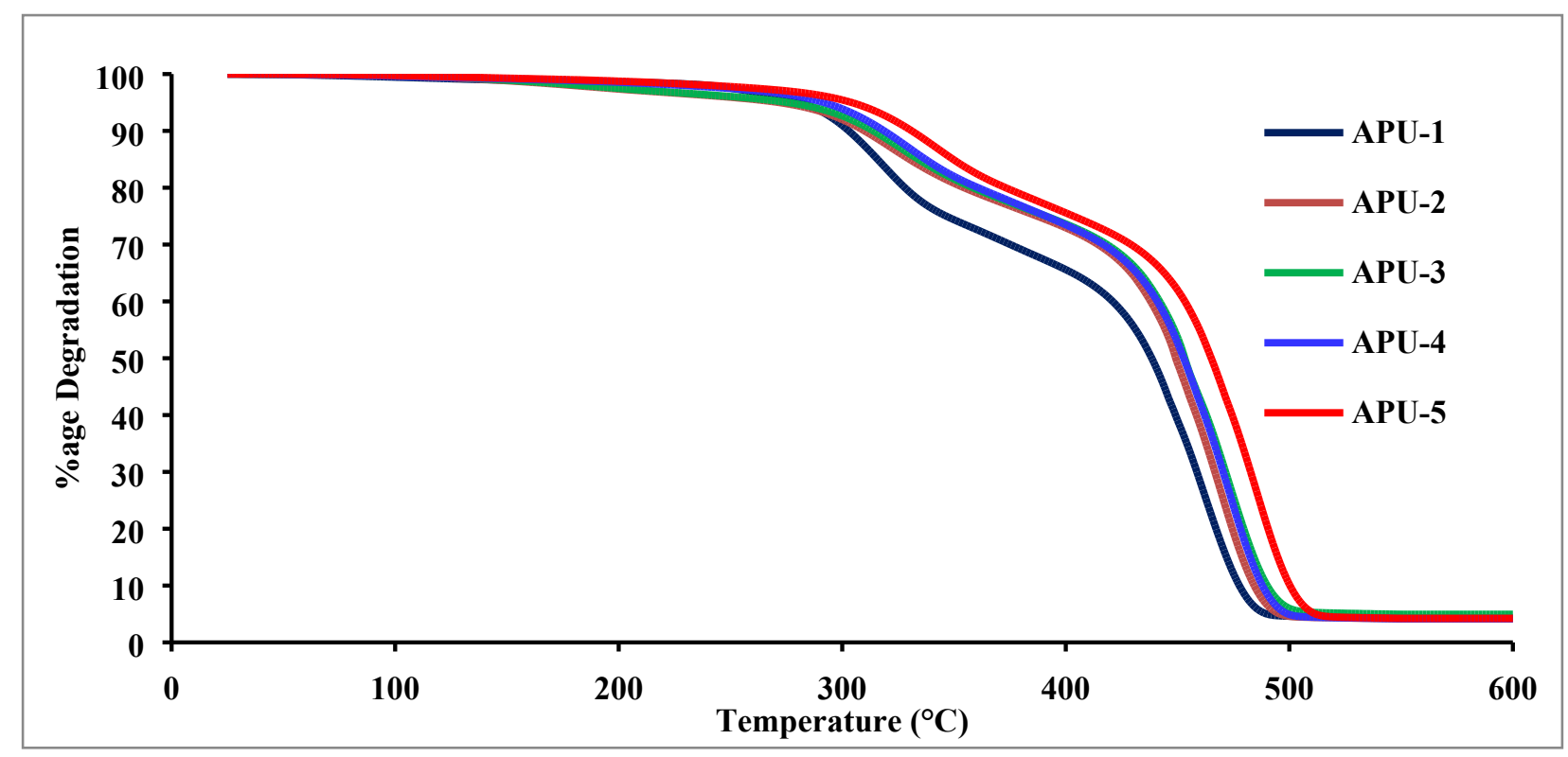

Fig. 5

TGA thermoanalytical curves of starch based PUs 
Table 1 Feed composition of BDO/starch modified polyurethanes.

\begin{tabular}{cccccc}
\hline $\begin{array}{c}\text { Sr. } \\
\text { No. }\end{array}$ & Sample code & $\begin{array}{c}\text { Starch } \\
(\mathbf{m o l e})\end{array}$ & $\begin{array}{c}\mathbf{1 , 4 - B D O} \\
(\text { moles })\end{array}$ & $\begin{array}{c}\text { HTPB }^{\mathbf{b}} \\
(\mathbf{m o l e s})\end{array}$ & $\begin{array}{c}\text { IPDI }^{\mathbf{c}} \\
\text { (moles) }\end{array}$ \\
\hline $\mathbf{1}$ & APU-1 & 0.0 & 2.0 & 1 & 3 \\
$\mathbf{2}$ & APU-2 & 0.5 & 1.5 & 1 & 3 \\
$\mathbf{3}$ & APU-3 & 1.0 & 1.0 & 1 & 3 \\
$\mathbf{4}$ & APU-4 & 1.5 & 0.5 & 1 & 3 \\
$\mathbf{5}$ & APU-5 & 2.0 & 0.0 & 1 & 3 \\
\hline
\end{tabular}
a. 1,4- Butanediol
b. Hydroxyl terminated polybutadiene
c. Isophorone diisocyanate 
Table 2 GPC profile of starch based polyurethanes

\begin{tabular}{ccccc}
\hline Sr. No. & Sample code & $\mathrm{M}_{\mathrm{n}}{ }^{\mathrm{a}}$ & $\mathrm{M}_{\mathrm{w}}{ }^{\mathrm{b}}$ & $\mathrm{Ð}^{\mathrm{c}}$ \\
\hline 1 & APU-1 & 9369 & 7198 & 1.3016 \\
2 & APU-2 & 13657 & 10479 & 1.3032 \\
3 & APU-3 & 14037 & 11953 & 1.1746 \\
4 & APU-4 & 14962 & 12138 & 1.2326 \\
5 & APU-5 & 16879 & 14255 & 1.1840 \\
\hline
\end{tabular}
a. Number average molecular weight
b. Weight average molecular weight
c. Polydispersity 
Table 3 Thermal degradation profile of PU films

\begin{tabular}{|c|c|c|c|c|c|c|c|c|}
\hline $\begin{array}{c}\text { Sr. } \\
\#\end{array}$ & $\begin{array}{l}\text { Sample } \\
\text { code }\end{array}$ & $\begin{array}{l}\mathrm{T}_{\mathrm{i}}^{\mathrm{a}} \\
\left({ }^{\circ} \mathrm{C}\right)\end{array}$ & $\begin{array}{l}\mathrm{T}_{10}{ }^{\mathrm{b}} \\
\left({ }^{\circ} \mathrm{C}\right)\end{array}$ & $\begin{array}{l}\mathrm{T}_{20}{ }^{\mathrm{b}} \\
\left({ }^{\circ} \mathrm{C}\right)\end{array}$ & $\begin{array}{l}\mathrm{T}_{50}{ }^{\mathrm{b}} \\
\left({ }^{\circ} \mathrm{C}\right)\end{array}$ & $\begin{array}{l}\mathrm{T}_{60}{ }^{\mathrm{b}} \\
\left({ }^{\circ} \mathrm{C}\right)\end{array}$ & $\begin{array}{l}\mathrm{T}_{80}{ }^{\mathrm{b}} \\
\left({ }^{\circ} \mathrm{C}\right)\end{array}$ & $\begin{array}{c}\text { Residue }^{c} \\
(\%)\end{array}$ \\
\hline 1 & APU-1 & 280 & 300 & 328 & 438 & 448 & 466 & 4.01 \\
\hline 2 & APU-2 & 276 & 305 & 354 & 448 & 457 & 474 & 4.09 \\
\hline 3 & APU-3 & 279 & 309 & 358 & 453 & 462 & 479 & 4.20 \\
\hline 4 & APU-4 & 292 & 314 & 360 & 452 & 462 & 479 & 4.15 \\
\hline 5 & APU-5 & 294 & 327 & 372 & 465 & 473 & 490 & 4.10 \\
\hline
\end{tabular}


Editor

\section{International Journal of Biological Macromolecules}

Dear Editor,

Enclosed is the paper, entitled: Ms Ref. No. IJBIOMAC_2019_7767_R1

Title: "Utilization of Waxy Corn Starch as an Efficient Chain Extender for the Preparation of Polyurethane Elastomers"

All the changes have been made in the light of reviewer's comments and suggestions. All the authors are agreed to submit this REVISED research article to your journal. Please accept it as a candidate for publication in International Journal of Biological Macromolecules. On acceptance of this manuscript all the authors are agreed to transfer of copyrights to the publisher of International Journal of Biological Macromolecules. In this research article, waxy corn starch has been utilized for the preparation of polyurethane to make it biodegradable. The materials have been characterized using advanced techniques (FTIR-ATR, ${ }^{1} \mathrm{H}$ NMR, GPC etc.). We believe that these results have considerable importance and in our knowledge, this study has not been reported up till now. The subject of this manuscript will be of great interest to scientists, researchers, and professionals, linked to fields of biomaterials, polymers, chemistry, and physics. This investigation comes under the present scope of your journal. Finally, this paper is our original unpublished work and it has not been submitted to any other journal for reviews.

Name, Affiliation and E-Mail Address of all the Co-authors:

\section{Muhammad Asif Javaid}

Department of Chemistry, University of Agriculture, Faisalabad 38040-Pakistan.

Email: asifjavaidchemist@gmail.com

\section{Khalid Mahmood Zia}

Department of Applied Chemistry, Government College University, Faisalabad 38030-Pakistan

Email: ziakmpkpolym@yahoo.com

\section{Amer Iqbal}

Department of Chemistry, University of Agriculture, Faisalabad 38040-Pakistan.

ameriqbal.chemist@gmail.com

Saliha Ahmad

Institute of Chemistry, Government College University, Faisalabad 38030-Pakistan.

Email: Salehaahmad2222@gmail.com

\section{Nadia Akram}

Department of Chemistry, Government College University, Faisalabad 38030-Pakistan.

Email: Nadiaakram@gcuf.edu.pk

\section{Xuqing Liu}

Department of Materials, University of Manchester, Oxford Road, Manchester, M13 9PL, UK

Email: xuqing.liu@manchester.ac.uk; Tel.:+44 (0) 1613064125

\section{Hifza Nawaz}

Department of Chemistry, Quaid-i-Azam University, Islamabad 45320, Pakistan

hafsanawaz1122@gmail.com;

Muhammad Kaleem Khosa

Department of Chemistry, Government College University, Faisalabad 38030-Pakistan

Email: mkhosapk@yahoo.com

Muhammad Awais

Department of Chemistry, Government College University, Faisalabad 38030-Pakistan.

Email: chemi.786@gmail.com

Sincerely,

Dr. Khalid Mahmood Zia (Corresponding Author)

Email: ziakmpkpolym@yahoo.com

Fax: +92-(41)-9200671; Tel: +92-(300)-660396 
Utilization of Waxy Corn Starch as an Efficient Chain Extender for the Preparation of Polyurethane Elastomers

\section{Supporting Information}

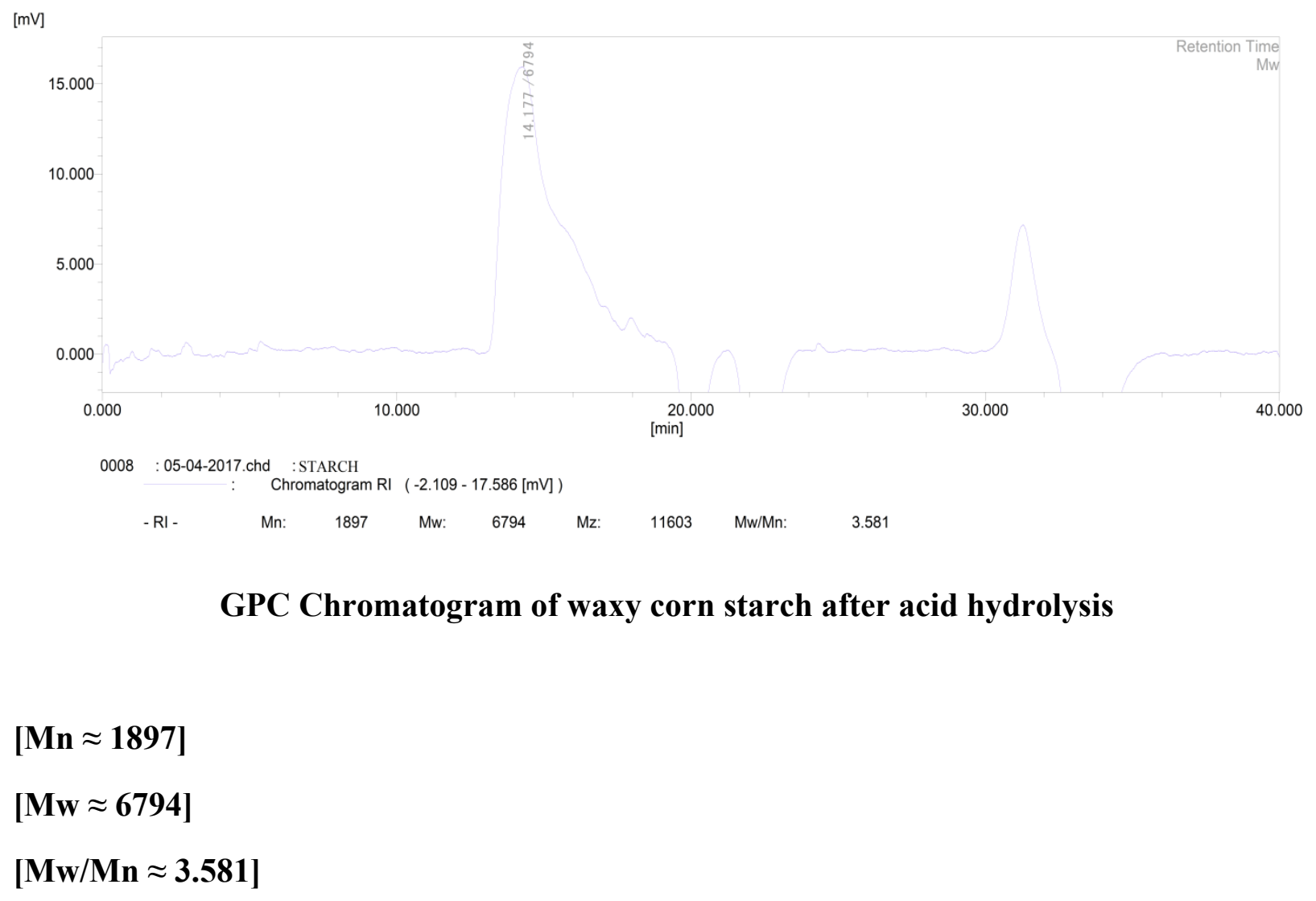

